one of the characters of this yolk is 'all-alikeness,' you at once perceive how nonsensical is their statement. You see that the substance of the yolk is not all-alike, and that therefore all-alikeness cannot be one of its attributes. Similarly with the other pretentious term 'heterogeneity,' which, according to them, describes the state things are brought to by what they call evolution. It is mere empty sound, as is manifest if I do but transform it, as I did the other, and say instead 'not-all-alikeness.' For on showing you this chick into which the yolk of the egg turns, you will see that 'not-all-alikeness' is a character which cannot be claimed for it. How can any one say that the parts of the chick are not-all-alike? Again, in their blatant language we are told that evolution is carried on by continuous 'differentiations'; and they would have us believe that this word expresses some fact. But if we put instead of it 'somethingelseifications' the delusion they try to practise on us becomes clear. How can they say that while the parts have been forming themselves the heart has been becoming something else than the stomach, and the leg something else than the wing, and the head something else than the tail? The like manifestly happens when for 'integrations' we read 'sticktogetherations' : what sense the term might seem to have, becomes obvious nonsense when the substituted word is used. For nobody dares assert that the parts of the chick stick together any more than do the parts of the yolk. I need hardly show you that now when I take a portion of the yolk between my fingers and pull, and now when I take any part of the chick, as the leg, and pull, the first resists just as much as the last-the last does not stick together any more than the first; so that there has been no progress in 'sticktogetherations.' And thus, gentlemen, you perceive that these big words which, to the disgrace of the Royal Society, appear even in papers published by it, are mere empty bladders which these would-be philosophers use to buoy up their ridiculous doctrines."

But though it is here, I think, made apparent enough that even when disguised in Mr. Kirkman's grotesque words, the definition of Evolution continues truly to express the facts, Prof. Tait shows no sign of changing his original opinion that Mr. Kirkman has made "an exquisite translation" of the definition. Nay, so charmed does he appear to be with Mr. Kirkman's feats of this nature, that he gires us another of them. One of two conclusions must be drawn. Prof. Tait either thinks that fallacies are disclosed by the aid of these cacophonous long words, or else the clatter of curious syllabic compounds greatly excites his sense of humour. In the last case we may infer that had he been one of that "Twelfth Night" party in which the Clown exclaims-"I did impeticos thy gratillity," he would have joined in Sir Andrew Aguecheek's applause.

HERBERT SPENCER

\section{NOTES ON THE GEOLOGY OF EAST-CENTRAL AFRICA}

THOUGH many travellers have now penetrated almost every part of Central Africa, and described the main geographical features, yet their accounts have been singularly barren in any reliable geological details. The Geographical Society, in its late expedition to the lake region, sought to remedy this want, and $\mathrm{I}$, as a student of that science, had the honour of being selected as geologist and assistant to Mr. Keith Johnston, the leader of the expedition.

After the lamentable death of Mr. Johnston, almost at the commencement of our journey, the entire work of the expedition fell into my inexperienced hands, and to perform that work conscientiously precluded all hope of anything but the most superficial geological research. The difficulties in the way were, as in all tropical countries, much increased by the luxuriance of the vegetation, which seldom leaves a rock uncovered and exposed to view.
Notwithstanding these obstacles to geological investigation, however, glimpses of the internal structure of the country traversed were here and there obtained, which I think may fairly be considered as shadowing forth the main general features of the geology of the Great Lake Region.

Let me briefly point these out in the order of their occurrence along our route to Nyassa and Tanganyika. The comparatively unbroken stretch of low-lying country which so markedly borders the East Coast of Africa is formed of two, if not three, raised beaches, elevated in recent times above the sea. They consist chiefly of brick-red sands and clays overlying coral rock. The former have been derived by denudation from the coast ranges, which, consisting of hornblende rocks and others containing a large amount of iron, easily account for the deep-red colour characterising these deposits. The sands are of value as containing the gum copal, of which our best varnishes are made. As the tree from which this gum has been derived is now almost extinct, it would seem that a considerable lapse of time has occurred since these deposits have been formed; but geologically they must be recent, as among the many insects that have been found imbedded in the copal none, as far as I am aware, are extinct. The Msandarusi, or gum copal tree, has evidently been restricted to the sea-coast, as neither it nor the gum has ever been found as yet in the interior.

In passing from these sands and clays we step over an immense gap in the geological record, of which no trace remains, as the rocks we next reach are evidently of carboniferous age. These occupy a variable strip along the base of the mountains, here and there rising into small hills and ranges.

They are found stretching from at least Mozambique to the Equator. On the Rovuma coal-beds are found. In the Rufigi valley there are red liver-coloured sandstones with pebbled beds and with interbedded lavas which in one curiously-shaped mountain near Behobeho produce a remarkable step-like appearance. These beds are horizontal, but beneath them are sandstones tilted by the intrusion of eruptive basalts, producing an unconformability which however is probably only local. Further north on the Unyanyembe road from Bogamoyo, and at the base of the mountain I observed on my return march compact beds of fossiliferous limestones, together with shales, \&c.

At Umba, a place north of Pangani, I also discovered limestone, which I believe is now being burnt by the Universities Mission Agents. The young geologist, Thornton, the companion of Baron von der Decken, observed this same formation around Mombas, which he noted as being exactly similar to the coal formation of the Zambesi. As no rocks of a later date have been found along the whole of the east coast from Mozambique to the Equator, we may safely infer that this part of the continent has been above water since Carboniferous times, and this inference is strengthened by natural history evidence.

We have now reached the base of the mountains, and again we are brought face to face with another great break in the series of events. From the Carboniferous sandstones and limestones we pass abruptly to highly metamorphosed rocks whose exact place in the geological series is as yet extremely problematical. These consist of the schists, gneiss, and hornblende rocks which form the mountain range that flanks the great Central Plateau extending from Abyssinia to the Cape.

In crossing this range we rose to a height of 7000 feet. We found the strike of the rocks to be north and south. They present every intermediate grade of variation from the most coarsely crystalline to those with the bedding still traceable. Indeed it would be somewhat difficult to point out any sharply-defined line of demarcation between the granites, which seem to predominate 
in the plateau, and the less metamorphosed rocks. It seems to me that this range suggests a line of weakness during the elevation of the continent, owing to which the neighbouring rocks were more easily folded up and raised above the line of greatest pressure, which has turned the main mass of the continent into granite. There is however some hope that more definite light will be thrown upon the question of the age of this range, as on my way back to the coast I discovered in the Usagara Mountains some much metamorphosed rocks with imperfectly pre-

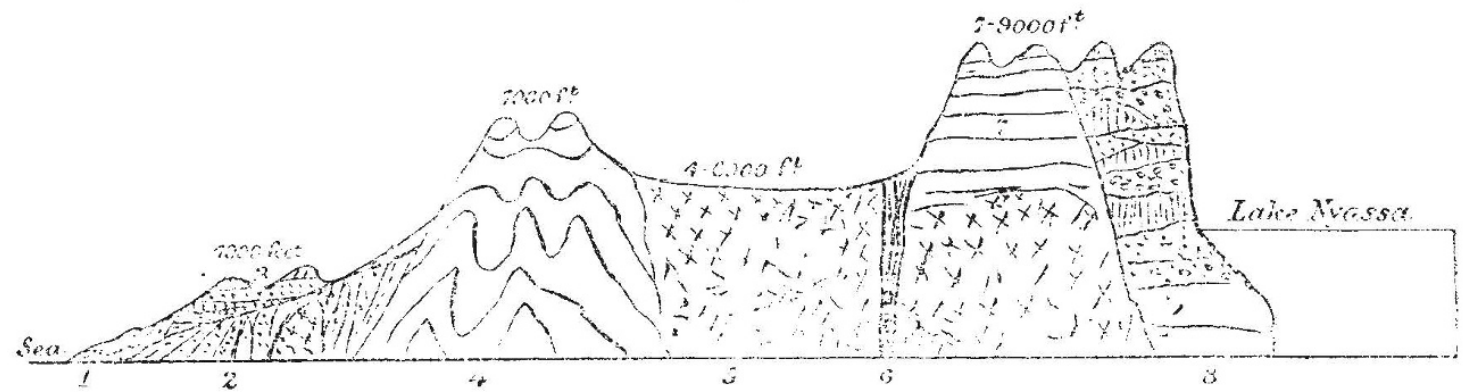

Section of Rocks between Dar-es-salaam and Lake Nyassa. I, Red sandy clays; 2, Carboniferous (?) sandstones with intrusive rocks: 3 , Carboniferous sandstones with interbedded lavas; 4, Schists, gneiss, and other hignly metamorphosed rocks; 5 . Granite forming main mass of the interior

6 , Intrusive rocks and probable line of fault; 7, Clay slates with occasional felspathic rocks; 8, Volcanic porphyrites, tuffs, and agslomerates.

served fossils. A carefil search would probably be re- This tract, extending to near the lakes, is marked by warded by the discovery of fossils which would determine undulating hills and valleys, with wide areas comparathe age of these rocks. Leaving the metamorphic rocks of the flanking range, the Wabena, Warori, Wahehi, Wagogo, and Masai herd
we next pass over a great stretch of granitoid rocks. their cattle, hunt, and live in a constant state of warfare.

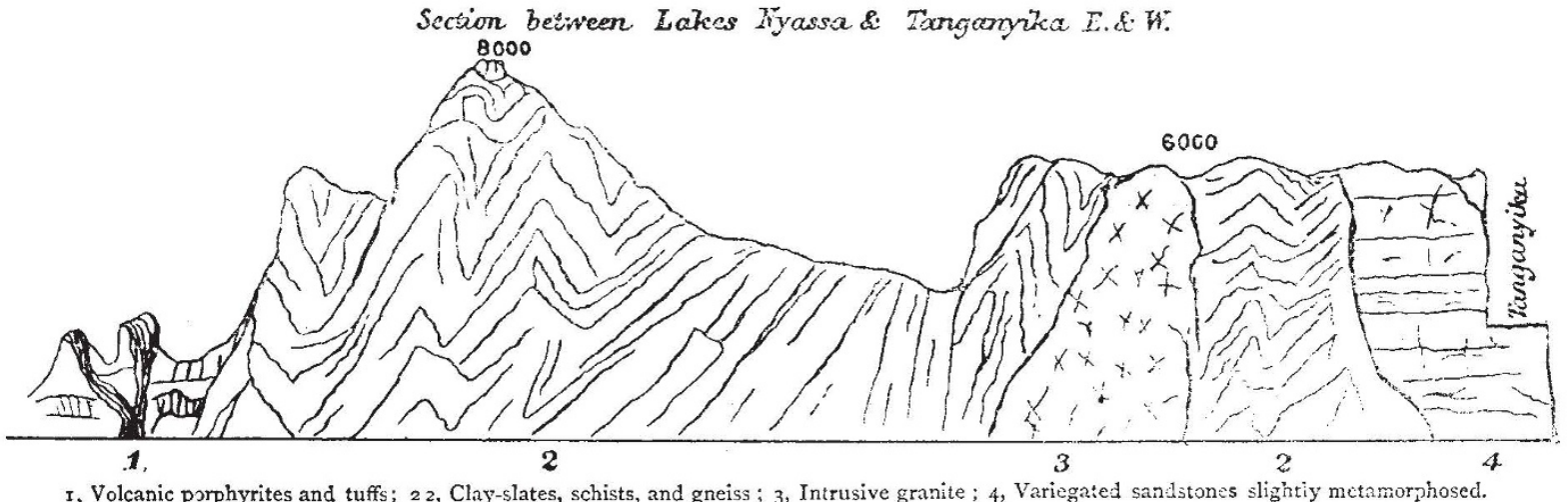

The influence which the character of the country has upon Urori, sandy as in Ugogo, or grey clay as in Unyamwesi. the habits and manners of savage tribes is here well The vegetation varies greatly according to the nature of illustrated.

The soil formed by the degradation of this granite tract is either a stiff red clay as occurs in Ubena and the soil. The whole of this granitoid region is marked by the occurrence of monstrous blocks, generally rounded, and strewing the whole surface as if some great eruption

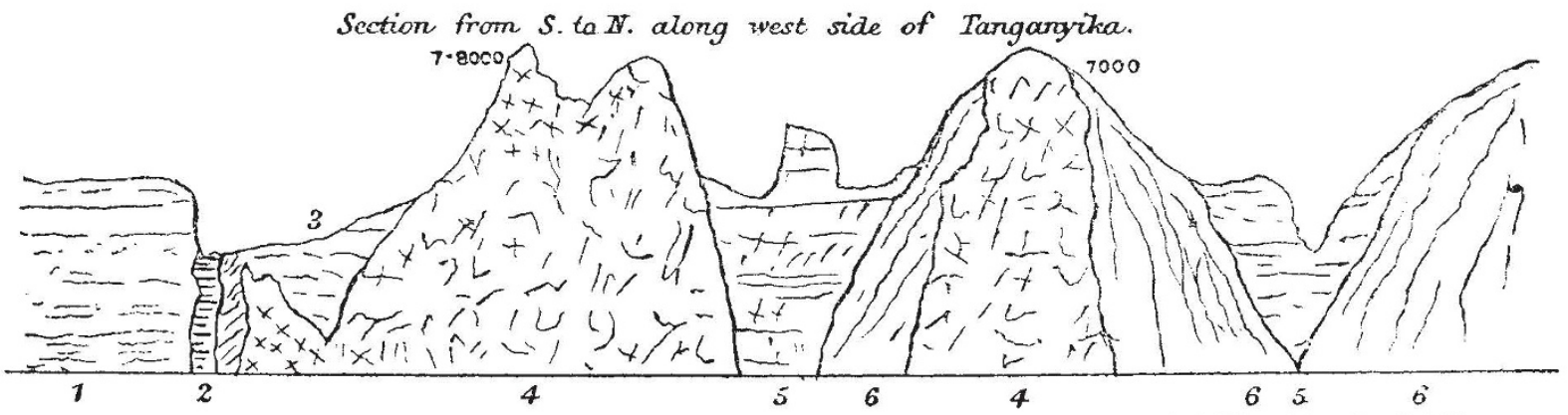

(1) Variegated sandstones; (2) Intruded rocks and probable line of fault; (3) Sandstenes smashed and tilted; (4.4) Felspaih:c rocks; (35) Fine grained brick-red sandstones with quartz pebbles; $(666)$ Greywacke and other metamorphic rocks.

had smashed the underlying rocks. Their presence, however, is not due to any such cause, the main agent having been rain and carbonic acid, assisted by rapid radiation acting along the joints and cracks.

It may be noted that at a number of points both in
Ubena and Ugogo evidences of rocks erupted through the granites were obtained.

Continuing our route to Nyassa over this plateau at a general height of about 5000 feet above the sea we are confronted by a sudden rise in the ground, which forms 
apparently a second and higher plateau. The abrupt change of level, together with the alteration in the internal structure and the presence of intrusive rocks at the base of the mountain seem to point to the existence of a fault of considerable magnitude, which probably is the eastward extension of a great fault to be described further on.

The rocks composing this high tract of country consist mainly of clay-slates with the original bedding still very distinet. What may be their exact relations to the granites which they probably overlie, or to the metamorphic rocks of the coast-range, we have as yet no means of ascertaining. Careful research will be required before anything definite can be said about them. The mountains cut out of these rocks by denudation are rounded in form, smooth, and by no means picturesque. They are devoid of trees, but covered with grass.

As we approach Lake Nyassa we observe evidence of much disturbance, till at a distance of about ten miles from the Lake we come upon the ancient pipe of a volcano, and five miles further on enter amongst a series of volcanic porphyrites, tuffs, and agglomerates forming mountains several thousands of feet in height, and which extend round the north end of the Lake. Along with this marked change of internal structure we have as decided a change in the scenery, The rounded mountains with smooth, grassy, and uncut sides give place to jagged peaks, serrated ridges, sharp yawning valleys, and irregular, rocky, notched sides, forming a landscape of no ordinary description.

The extraordinary scries of volcanic rocks which form the magnificent mountains round the north end of Lake Nyassa probably belong to the same period as a similar series which characterise the Cape geology. The latter have been assigned to the Trias, and doubtless the immense development of volcanic rocks in Abyssinia described by Blandford is of the same age. Indeed we might almost say we have connecting links between the two places, as on my return march through Ugogo I observed evidence of volcanic outbursts, and it is well known that Kilimanjaro, further north, is of volcanic origin. It seems then that in Triassic times a great line of volcanic action stretched from the Cape by Nyassa, Ugogo, and Kilimanjaro, to Abyssinia.

But at the north-west corner of Nyassa we have evidence of later volcanic activity. In a niche cut out of the surrounding plateau and on a comparatively level plain, through which the River Jumbaka winds to the lake, a number of beautifully isolated cones rise to a height of about 300 feet. On examination these prove to be perfect volcanic craters, so entire and symmetrical as to appear almost artificial. One crater which I examined forms a beautifully bowl-shaped hollow, descending to the level of the plain, the bottom being a charming circular pond, where a number of hippopotamuses live.

It is clear from the perfect shapes of these cones, and from the fact that the surface features of the surrounding country have remained unchanged since their origin, that they must have arisen in comparatively recent times. Besides these cones there are two pretty circular lakes, which also appear to have been originally volcanic craters.

On leaving this interesting country and proceeding on our way to Tanganyika we rise once more to the top of the plateau, cross over mountains 8000 feet in height, and then descend to a general level of from 4000 to 6000 feet. We pass over clay slates and schists whose relative positions could not be determined with intrusive masses of granite. At one point an interesting section was revealed, showing the granite completely inclosing a mass of greenstone.

On nearing the south end of Lake Tanganyika we pass abruptly from these ancient rocks to red and variegated sandstones much hardened and broken, but prescrving their original horizontal bedding. Rounding the end of the lake and continuing our march northward along its western side, we come to almost a sheer precipice, suddenly lowering the altitude from nearly 5000 feet to less than 3000 . Running east and west along the precipice there occur intruded rocks, while on the northern or lower side of the precipice the sandstones almost disappear, being only represented by a small extent of crushed and tilted beds. Such a condition of things clearly indicates the existence of a great fault. This theory is strengthened by a similar abrupt change of rocks on the eastern side of the lake; and it will be remembered that we have already noticed among a different series of rocks still further east a sudden change of level almost on the same parallel of latitude.

The sandstones thus abruptly brought to a finish in their extension northward are succeeded by felspathic rocks which form huge mountain masses both on the east and west sides of the lake. Near the middle of the lake on its western side there occurs a curious apparently isolated area of fine red sandstones, surrounded on all sides except the east by mountains of metamorphic and felspathic rocks. These sandstones would seem to have been deposited in a small lake eight miles in diameter. Mount Malumbi, figured in Stanley's "Dark Continent," belongs to the same formation.

Still proceeding along the lake we cross a high mountain range named Tchansa, formed of metamorphic rocks with felspathic rock in the centre. We regain the sandstones once more in the country of Uguha. The sandstones here, unlike those of the south end, are very red in colour, extremely friable, and marked by the abundance of quartz pebbles. Through this formation the Lukuga River finds its way to the Congo, its course determined not by any great convulsion as some travellers have been inclined to believe, but by the long-continued action of streams wearing down the soft and friable barrier which hemmed in the lake at this point. These sandstones have an extension over a large area. They are found away towards Manyema and up the Congo Valley as far as Lake Moero, probably turning round and joining the strata we have noticed at the south end of Tanganyika. On the east side they are found from Kaboga to the north of Ujiji, though here shales are not uncommon and the strata much curved.

The absence of all fossils leaves the question of the age of these rocks in some mystery. A reference to Cape geology may, however, as in the case of the volcanic rocks, throw some light on this subject. The Tanganyika sandstones have evidently been formed in an enormous inland lake, beside which the present African lakes would look insignificant.

In Cape Colony a similar series of rocks occur of a lacustrine origin, and which have been assigned to a period not later than the Trias, and probably they belong to Palæozoic times. In the absence of anything but lithological evidence we cannot do better than place the Tanganyika sandstones in the same era as the Cape series, an era which would seem to have been emphatically characterised by the presence of great lakes.

JOSEPH THOMSON

\section{INCANDESCENT ELECTRIC LIGHTS}

T

$\mathrm{HE}$ recent experiments of Mr. J. W. Swan of Newcastle-on-Tyne have gone far towards demonstrating the practicabilty of a system of electric lighting based upon the so-called principle of incandescence. As the solution of the whole question of the possible domestic application of electric lighting depends in all probability uppon the successful application of this method, thcse experiments have claimed already a considerable share of public attention, though no panic has yet arisen like 